Article

\title{
Estrogenic, Antiestrogenic and Antiproliferative Activities of Euphorbia bicolor (Euphorbiaceae) Latex Extracts and Its Phytochemicals
}

\author{
Paramita Basu, Elizabeth Meza, Michael Bergel * and Camelia Maier *(D) \\ Department of Biology, Texas Woman's University, Denton, TX 76204-5799, USA; pbasu@twu.edu (P.B.); \\ emeza2@twu.edu (E.M.) \\ * Correspondence: mbergel@twu.edu (M.B.); cmaier@twu.edu (C.M.); \\ Tel.: +1-940-898-2471 (M.B.); +1-940-898-2358 (C.M.)
}

Received: 2 December 2019; Accepted: 23 December 2019; Published: 25 December 2019

\begin{abstract}
Estrogen receptor antagonists are effective in breast cancer treatment. However, the side effects of these treatments have led to a rise in searching for alternative therapies. The present study evaluated the estrogenic, antiestrogenic, and antiproliferative activities of Euphorbia bicolor (Euphorbiaceae), a plant native to south-central USA. Estrogenic and antiestrogenic activities of latex extract and its phytochemicals were evaluated with a steroid-regulated yeast system expressing the human estrogen receptor $\alpha$ and antiproliferative properties were assessed in the ER-positive MCF-7 and T47-D and triple-negative MDA-MB-231 and MDA-MB-469 breast carcinomas. Genistein and coumestrol identified in the latex extract induced higher estrogenic and antiestrogenic activities compared to diterpenes and flavonoids. The latex extract, resiniferatoxin (RTX) and rutin induced antiproliferative activities in all cell lines in a dose-dependent manner, but not in human normal primary dermal fibroblast cultures. A biphasic effect was observed with MDA-MB-468 breast carcinoma in which the latex extract at low concentrations increased and at high concentrations decreased cell proliferation. Treatments with latex extract in combination with RTX or rutin reduced even more the proliferation of MCF-7 breast carcinoma compared to the individual latex, RTX, and rutin treatments. E. bicolor latex phytochemicals could contribute to developing commercial therapeutic agents for breast cancer treatment.
\end{abstract}

Keywords: breast cancer; Euphorbia bicolor; resiniferatoxin; rutin; latex; MCF-7; T47-D; MDA-MB-231; MDA-MB-469

\section{Introduction}

Breast cancer is one of the most frequently diagnosed cancers in women. In 2018, 25.4\% of the total number of new cases diagnosed were breast cancer [1]. According to the National Cancer Institute, 268,600 (15.2\%) new cases of breast cancer have been estimated so far in 2019 [2]. Estrogen receptors, present in approximately $75 \%$ of breast cancers, are known to play important roles in the initiation and progression of breast cancer ([3]; and references within). Estrogen receptor alpha especially is an important target for drug development for the prevention and treatment of breast cancer [4] and estrogen receptor positive (ER+) tumors show relatively better prognoses for treating breast cancer as compared to ER-negative breast cancer, especially the triple negative breast cancer, which does not express the hormone epidermal growth factor receptor 2 (HER-2), estrogen receptors (ER), and progesterone receptors (PR) [5].

The biological activities of estrogens are mediated by both genomic and non-genomic pathways [6]. Through the genomic pathway, estrogen binds to the estrogen receptors (ER), which then translocate 
to the nucleus, where the estrogen-receptor complex interacts with the estrogen response elements (ERE) present in the promoters of the target genes, recruits co-activators, and initiates transcription of those genes. The effects of estrogen are also mediated via DNA-binding transcription factors (activator protein-1, nuclear factor- $\mathrm{kB}$, and stimulating protein-1), which mediate ER association with the DNA. Estrogen also elicits its activity via different non-genomic signaling pathways, such as NF-kB, PI3K/Akt/mTOR, and MAPK/ERK associated with growth factor activation [7]. ER $\alpha$, present in approximately $75 \%$ of breast cancers [8], is known to play important roles in the initiation and progression of breast cancer [9]. Therefore, $\mathrm{ER} \alpha$ is an important target for drug development for the prevention and treatment of breast cancer [10].

Breast cancers are mainly treated with surgery, radiotherapy, chemotherapy, SERMs (tamoxifen), estrogen receptor down-regulators (fulvestrant), aromatase inhibitors (anastrozole, exemestane, letrozole), several drugs (ado-trastuzumab emtansine, lapatinib, palbociclib, pertuzumab, and trastuzumab), antimetabolites (methotrexate), DNA-interactive agents (cisplatin, doxorubicin), antitubulin agents (taxanes), etc. [11,12]. However, the clinical uses of the drugs are accompanied by several side effects, such as neurological dysfunction, hair loss, drug resistance, bone marrow suppression, gastrointestinal lesions, etc. $[11,13,14]$. Therefore, researchers have focused on the search for new anticancer agents with better efficacy and less side effects. Several studies have reported plant-derived bioactive compounds with anticancer properties that inhibit cell cycle regulators, cell proliferation, angiogenesis, metastasis and different signaling pathways (NF- $\mathrm{B}, \mathrm{PI} 3 \mathrm{~K} / \mathrm{Akt} / \mathrm{mTOR}$, and MAPK/ERK), induce apoptosis, modulate estrogen biosynthesis and metabolism, and reverse multidrug resistance ([15]; and references within). Natural products have long been a prominent source of anti-cancer drugs, representing 48.6\% of those FDA-approved drugs since 1940 [16].

Euphorbiaceae species are known to possess anticancer properties by inducing apoptosis and cell cycle arrest [17,18], inhibiting cell proliferation [19], and also reversing the multidrug resistance [20] of different breast cancer cell lines. Snow-on-the-prairie, Euphorbia bicolor (Spurge family, Euphorbiaceae), a species native to south-central USA have not been studied before. The present study evaluated the estrogenic, antiestrogenic and antiproliferative properties of E. bicolor (Euphorbiaceae) latex extract and its phytochemicals. We report that the E. bicolor latex extract and its phytochemicals induced estrogenic and antiestrogenic properties in a steroid-regulated yeast system and also possessed antiproliferative properties in ER-positive MCF-7 and T47-D and triple negative MDA-MB-231 and MDA-MB-469 breast carcinomas without affecting the growth of the human normal primary dermal fibroblast cell line. To our knowledge, this is the first study reporting the estrogenic, antiestrogenic, and antiproliferative properties of E. bicolor latex extract and resiniferatoxin (TRX) on ER-positive T47-D and triple-negative MDA-MB-469 breast carcinomas.

\section{Materials and Methods}

\subsection{Plant Collection and Preparation of Latex Extract}

E. bicolor plants were collected from prairies in Denton County, Texas, USA. The extracts were prepared by the same method as Basu et al. [21]. Fresh latex was collected from different plant organs in pre-weighed vials and extracted in $80 \%$ methanol $(1: 40 w / v)$ at room temperature for two days. The extract was centrifuged at $3500 \mathrm{rpm}$ for 20 minutes and the supernatant was filtered through Whatman \#54 filter paper (Thomas Scientific, Swedesboro, NJ, USA) and stored at $-20{ }^{\circ} \mathrm{C}$ for future use.

\subsection{Identification of Latex Phytochemicals by UPLC-ESI-MS/MS}

Latex phytochemicals were identified by employing ultra-performance liquid chromatography electrospray ionization tandem mass spectrometry (UPLC-ESIMS/MS) [21]. A Waters Acquity UPLC (Waters Corporation, Milford, MA, USA) chromatography system, coupled with ESI Xevo TQD triple quadrupole mass spectrometer, was used for phytochemicals identification. Latex phytochemicals were separated in a positive ionization mode in a Restek Raptor biphenyl 
column $(100 \mathrm{~mm}$ length $\times 2.1 \mathrm{~mm}$ diameter $\times 1.8$ micrometer particle size $)$. Chromatographic analyte separations were carried out using a gradient mobile phase consisting of $0.1 \%$ formic acid in $10 \mathrm{mM}$ ammonium formate and $0.1 \%$ formic acid in acetonitrile under linear gradient conditions (A:B \% v/v, 0-0.5 min: 80:20; 0.5-14 $\mathrm{min}: 30: 70 ; 14-15 \mathrm{~min}: 80: 20)$ at $0.6 \mathrm{~mL} / \mathrm{min}$ flow rate. The column temperature was maintained at $50{ }^{\circ} \mathrm{C}$. Cone gas flow of $10 \mathrm{~L} / \mathrm{h}$, desolvation gas flow of $1000 \mathrm{~L} / \mathrm{h}$, capillary voltage of $0.70 \mathrm{kV}$, source temperature of $150{ }^{\circ} \mathrm{C}$, and desolvation temperature of $450{ }^{\circ} \mathrm{C}$ were maintained for the source-dependent parameters. Ion detection was performed in the multiple-reaction monitoring (MRM) mode by monitoring the transition pairs. The compounds were identified based on standards prepared in methanol.

\subsection{Estrogenic and Antiestrogenic Assays}

A steroid-regulated Saccharomyces cerevisiae system, BJ3505 [MAT a, pep 4: His 3, prb 1- $\Delta$ 1.6 R, his 3- $\Delta$ 200, lys 2-801, trp 1- $\Delta$ 101(gal3), ura 3-52(gal 2), can 1], containing a human ER $\alpha$ expression plasmid and a $\beta$-galactosidase gene reporter plasmid was used to determine the estrogenic and antiestrogenic activities of latex extract and its phytochemicals [22,23]. The estrogenic and antiestrogenic assays were performed by the modified method of Maier et al. [24]. In brief, stock yeast cultures were grown in a casamino acid-glucose medium (20\% glucose, $10 \%$ YNB, and 5\% adenine sulfate) at $230 \mathrm{rpm}, 30^{\circ} \mathrm{C}$, overnight in an incubator-shaker. An estradiol (E) standard curve was used to estimate the estrogen equivalents (E equiv) in the latex extract. Ten milliliter of yeast subcultures were inoculated with $100 \mu \mathrm{g}, 200 \mu \mathrm{g}, 300 \mu \mathrm{g}$, or $400 \mu \mathrm{g}$ E equivalents of E. bicolor latex extract or its identified phytochemicals at concentrations of $0.5,1$, and $5 \mu \mathrm{M}$. Cultures were grown for 6 hours after inoculation with latex extract or phytochemicals. Estradiol and genistein were used as positive controls. Yeast cultures without any treatments were used as negative controls. Estrogenic activity experiments were repeated three times and each experiment had two replicates.

For antiestrogenic assays, the yeast cultures were inoculated with estradiol and $100 \mu \mathrm{g}, 200 \mu \mathrm{g}$, $300 \mu \mathrm{g}$, or $400 \mu \mathrm{g}$ E equivalents of latex extract or phytochemicals resiniferatoxin (RTX) and rutin at concentrations of $0.5,1$, and $5 \mu \mathrm{M}$. The antiestrogenic activity translates in a reduction of the transcriptional activity induced by estradiol in transgenic yeast due to the interference or competition of latex extract and phytochemicals with estradiol for the ligand-binding site of the ER. Antiestrogenic activity experiments were performed with two replicates each repeated three times.

Yeast cells were disrupted with glass beads $(0.5 \mathrm{~mm}$ diameter; BioSpec Products, Inc., Bartlesville, OK, USA) and the protein concentrations were estimated spectrophotometrically using the Bio-Rad protein assay dye reagent (BioRad, Berkeley, CA, USA). $\beta$-galactosidase assays were performed by incubating estimated amount of protein in Z-buffer $\left(0.006 \mathrm{M} \cdot \mathrm{Na}_{2} \mathrm{HPO}_{4} \cdot 7 \mathrm{H}_{2} \mathrm{O}\right.$, $0.04 \mathrm{M} \mathrm{NaH}_{2} \mathrm{PO}_{4} \cdot \mathrm{H}_{2} \mathrm{O}, 0.01 \mathrm{M} \mathrm{KCl}, 0.001 \mathrm{M} \cdot \mathrm{MgSO}_{4}$, and $0.05 \mathrm{M} \beta$-mercaptoethanol), and $4 \mathrm{mg} / \mathrm{mL}$ ortho-Nitrophenyl- $\beta$-galactoside (ONPG). The reaction mixtures were incubated at room temperature for 30 minutes and terminated by adding $500 \mu \mathrm{L}$ of $1 \mathrm{M} \mathrm{Na}_{2} \mathrm{CO}_{3}$. The $\beta$-galactosidase activity of each reaction was measured spectrophotometrically at $420 \mathrm{~nm}$. Estrogenic activities of the latex extract and phytochemicals were expressed in Miller Units (MU) (Equation (1)).

$$
M U=1000 \times \frac{(\text { Abs at } 420 \mathrm{~nm})}{\text { Protein Concentration }[g] \times \text { Reaction Time }[\mathrm{min}]}
$$

Antiestrogenic activities of the latex extract and phytochemicals were calculated according to Equation (2) and expressed as \% inhibition of estradiol activity.

$$
M U=100-1000 \times \frac{(\text { Abs at } 420 \mathrm{~nm})}{\text { Protein Concentration }[\mathrm{g}] \times \text { Reaction Time }[\mathrm{min}]}
$$

Abs = Absorbance 


\subsection{Cell Lines and Cell Culture Conditions}

Estrogen receptor positive MCF-7 and T-47D, triple negative MDA-MB-231 and MDA-MB-468 breast cancer cell lines, and adult human normal primary dermal fibroblast were obtained from American Type Culture Collection (ATCC, Manassas, VA, USA). MCF-7 and MDA-MB-231 breast carcinomas were maintained in Dulbecco's Modified Eagle's Medium (DMEM; ThermoFisher Scientific, Township, NJ, USA), supplemented with 10\% heat-inactivated fetal bovine serum (Gemini), $1 \%$ penicillin and streptomycin (Gibco/BRL). Cells were grown in a humidified atmosphere of $5 \% \mathrm{CO}_{2}$ at $37{ }^{\circ} \mathrm{C}$. T-47D cells were maintained in RPMI-1640 medium, (ATCC), containing 0.2 Units $/ \mathrm{ml}$ bovine insulin; 10\% fetal bovine serum and human insulin (Life Technologies, Carlsbad, CA, USA). MDA-MB-468 cells were maintained in Leibovitz's L-15 medium (ATCC), containing 10\% fetal bovine serum and in absence of $\mathrm{CO}_{2}$. All cell lines were maintained in the logarithmic growth phase by routine passage every $2-3$ days using $0.025 \%$ trypsin-EDTA treatment. After $75 \%-80 \%$ confluency, the cells were trypsinized and transferred to a DMEM, high glucose, no glutamine, no phenol red free medium (Gibco, Life Technologies), supplemented with sodium pyruvate (Gibco, Life Technologies) and GlutaMAX ${ }^{\mathrm{TM}}$ supplement (Gibco, Life Technologies). Cells were maintained in phenol-red free medium until they reached $75 \%-80 \%$ confluency and then seeded in 96 -well plates. Human normal primary dermal fibroblast cells were grown in fibroblast basal medium (ATCC) supplemented with fibroblast growth kit-low serum (ATCC). Cells were grown in $5 \% \mathrm{CO}_{2}$ at $37^{\circ} \mathrm{C}$.

\subsection{Cell Culture Treatments}

All cells were seeded into 96-well cell culture plates at $9 \times 10^{3}$ cells/well and incubated for $24 \mathrm{~h}$ at $37^{\circ} \mathrm{C}$. After $24 \mathrm{~h}$, the cells were treated with different concentrations of E. bicolor latex extract $(1.96 \mu \mathrm{g} / \mathrm{mL}, 3.91 \mu \mathrm{g} / \mathrm{mL}, 7.81 \mu \mathrm{g} / \mathrm{mL}, 15.63 \mu \mathrm{g} / \mathrm{mL}, 62.5 \mu \mathrm{g} / \mathrm{mL}, 125 \mu \mathrm{g} / \mathrm{mL}, 250 \mu \mathrm{g} / \mathrm{mL}, 500 \mu \mathrm{g} / \mathrm{mL})$ and its identified phytochemicals RTX and rutin at $0.5 \mu \mathrm{M}, 1 \mu \mathrm{M}, 5 \mu \mathrm{M}, 10 \mu \mathrm{M}, 50 \mu \mathrm{M}, 100 \mu \mathrm{M}$, $250 \mu \mathrm{M}$, and $500 \mu \mathrm{M}$ concentrations. The extract and its phytochemicals were re-suspended in less than $0.1 \%$ DMSO. Human normal primary dermal fibroblast cells were treated with the abovementioned concentrations of latex extract or phytochemicals RTX or rutin.

In another series of experiments, latex extract and RTX or rutin were added individually or in combination to MCF-7 cells. The final concentration of DMSO was $<0.5 \%$. After treatment with the combination of latex extract and its phytochemicals, the MCF-7 cells were grown at $37{ }^{\circ} \mathrm{C}$ for $72 \mathrm{~h}$. Antiproliferative activity was evaluated by preforming MTS [3-(4,5-dimethylthiazol-2-yl)-5-(3-carboxymethoxyphenyl)-2-(4-sulfophenyl)-2H-tetrazolium] assay (Promega, Madison, WI, USA). The medium was removed and fresh medium with MTT was added to each well for $3 \mathrm{~h}$ at $37^{\circ} \mathrm{C}$. Plate readings were taken at $490 \mathrm{~nm}$ using a Biotek's Synergy HT plate reader. Antiproliferative assays were performed as three independent experiments each with three replicates.

\subsection{Statistical Analyses}

Means and standard errors of the mean were calculated. One-way ANOVA followed by Tukey's posthoc test were performed to determine the significant differences $(p \leq 0.05)$ among the means for the antiproliferative assays using GraphPad Prism 7. Estrogenic and antiestrogenic activities were analyzed by two-way ANOVA followed by Bonferroni's posthoc at $p \leq 0.05$. Growth inhibition $\left(\mathrm{GI}_{50}\right)$ values were calculated by linear regression analysis.

\section{Results}

\subsection{Estrogenic Activities of Latex Extract and Its Phytochemicals in a Steroid-Regulated Yeast System}

To test the estrogenic activities of E. bicolor latex extract and its identified phytochemicals, a steroid-regulated yeast system expressing ER $\alpha$ was employed. Latex extract in the range of 100 E-400 E equivalents induced low, not dose-dependent estrogenic activities ranging from $115.3 \pm 6.3$ to $121.7 \pm 7.8 \mathrm{MU}$ (Figure 1a). Coumestrol (Figure 1b) and genistein (Figure 1d) significantly induced 
estrogenic activities in a dose-dependent manner at $0.5,1$, and $5 \mu \mathrm{M}$. Abietic acid $(84.4 \pm 13.1 \mathrm{MU})$ (Figure 1b), RTX (88.3 $\pm 11.9 \mathrm{MU})$ (Figure 1b), and daidzein (87.4 $\pm 10.9 \mathrm{MU})$ (Figure 1d) showed low estrogenic activities at all concentrations tested. Estrogenic activities of all flavonoids identified in latex extract (chalcone, kaempferol, naringenin, quercetin, and rutin) were 90-100 MU at all concentrations (Figure 1c). No significant differences were observed among the estrogenic activities induced by all concentrations $(0.5,1,5 \mu \mathrm{M})$ of flavonoids chalcone, kaempferol, naringenin, quercetin, and rutin tested in the present study (Figure 1c).

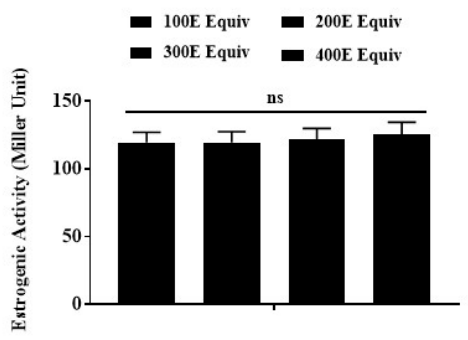

(a)

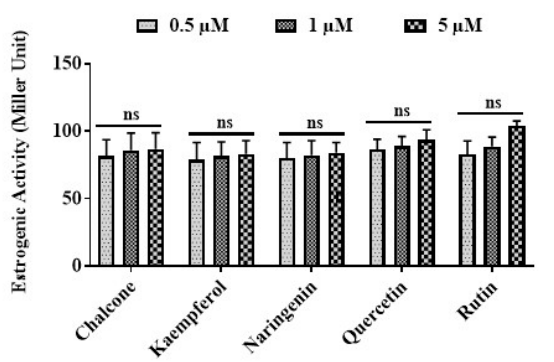

(c)

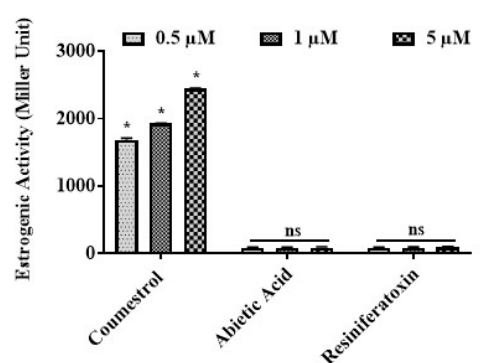

(b)

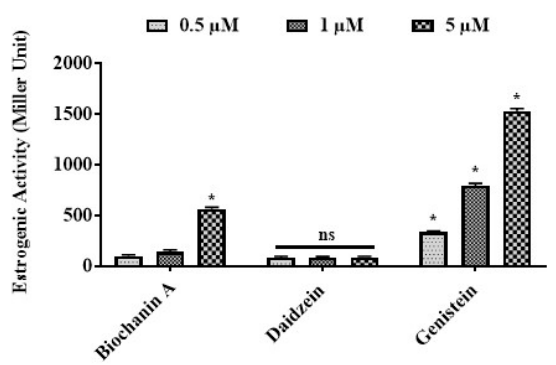

(d)

Figure 1. Estrogenic activities of E. bicolor latex extract and its phytochemicals in a steroid-regulated yeast system (BJ3505): (a) E. bicolor latex extract; (b) and its phytochemicals, coumestans (coumestrol) and diterpenes (abietic acid, resiniferatoxin (RTX)); (c) flavonoids (chalcone, kaempferol, quercetin, naringenin, quercetin, and rutin); (d) and isoflavones (biochanin A, daidzein, genistein). The average activities for positive controls estradiol and genistein were $2353.33 \pm 166.6$ and $998.9 \pm 46.5 \mathrm{MU}$, respectively. The activity of yeast cultures without any treatments (negative control) ranged from $12.2 \pm 0.8$ to $24.8 \pm 9.3 \mathrm{MU}$. Estrogenic activity of latex extract was analyzed by one-way ANOVA followed by Tukey's posthoc test at $p \leq 0.05$. Estrogenic activity of latex phytochemicals was analyzed by two-way ANOVA followed by Bonferroni posthoc test at $p \leq 0.05$. Bars with asterisks for each group of chemicals tested are significantly different from each other. ns = non-significant.

\subsection{Antiestrogenic Activities of Latex Extract and Its Phytochemicals in a Steroid-Regulated Yeast System}

To test for antiestrogenic activity, yeast cells were treated with estradiol and E. bicolor latex extract or its identified phytochemicals. The latex extract induced antiestrogenic activity by dose-dependently inhibiting the estradiol activity in the steroid-regulated yeast system. At 400 E equivalents, the latex extract inhibited estradiol activity by 50\% (Figure 2a). Coumestrol (Figure 2b) and the isoflavones daidzein and genistein (Figure 2d) showed significantly higher antiestrogenic activities compared to other latex phytochemicals by inhibiting the estradiol activity by $70.7 \%, 70 \%$, and $90.2 \%$, respectively. Antiestrogenic activities of all flavonoids identified in latex extract, chalcone, kaempferol, naringenin, quercetin, and rutin were $10.3 \%-44 \%$ at all concentrations $(0.5,1$, and $5 \mu \mathrm{M})$ (Figure $2 \mathrm{c}$ ). No significant 
differences were observed among the antiestrogenic activities induced by all concentrations of the flavonoids chalcone, quercetin, kaempferol, rutin and naringenin tested in the present study (Figure 2c).

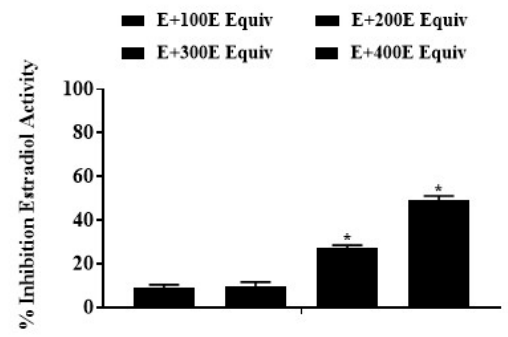

(a)

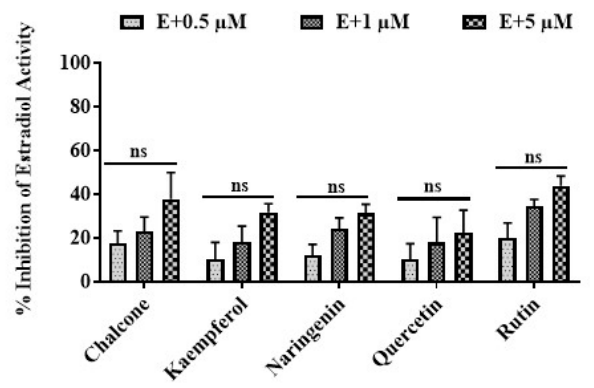

(c)

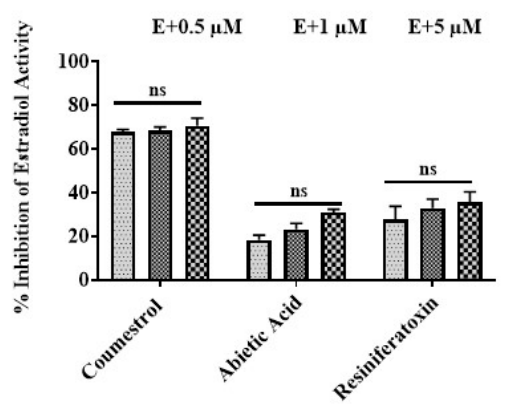

(b)

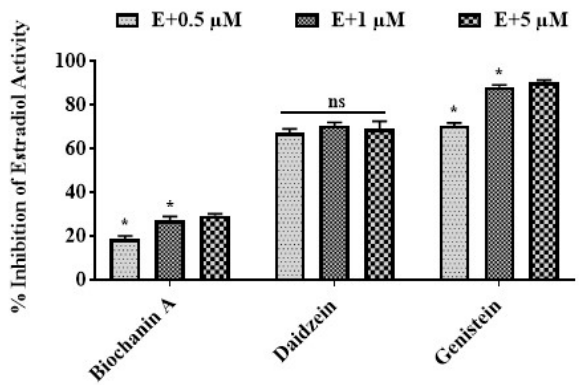

(d)

Figure 2. Antiestrogenic activities of E. bicolor latex extract and its phytochemicals in a steroid-regulated yeast system (BJ3505): (a) E. bicolor latex extract; (b) its phytochemicals coumestans (coumestrol) and diterpenes (abietic acid, RTX); (c) flavonoids (chalcone, kaempferol, quercetin, naringenin, quercetin, and rutin); (d) and isoflavones (biochanin A, daidzein, genistein). The average activity of estradiol (positive control) was $2353.33 \pm 166.6 \mathrm{MU}$. The estrogenic activity of yeast cultures without any treatments (negative control) ranged from $12.2 \pm 0.8$ to $24.8 \pm 9.3 \mathrm{MU}$. Antiestrogenic activity of latex extract was analyzed by one-way ANOVA followed by Tukey's posthoc test at $p \leq 0.05$. Antiestrogenic activity of latex phytochemicals were analyzed by two-way ANOVA followed by Bonferroni posthoc test at $p \leq 0.05$. Bars with asterisks are significantly different from each other. $\mathrm{ns}=$ non-significant.

\subsection{Antiproliferative Activities of Latex Extract and Its Phytochemicals on ER-Positive and Triple Negative Breast Cancer Cell Lines}

To test the antiproliferative activities of E. bicolor latex extract and its identified phytochemicals RTX and rutin, ER-positive MCF-7 and T47-D and triple negative MDA-MB-231 and MDA-MB-468 breast carcinomas were employed. The E. bicolor latex extract dose-dependently inhibited the proliferation of both ER-positive cell lines, MCF-7 and T47-D (Figure 3a,b). At $500 \mu \mathrm{g} / \mathrm{mL}$, the proliferation of MCF-7 and T47-D cells were significantly reduced by $61.1 \%$ and $65 \%$, respectively (Figure $3 a, b$ ). The $\mathrm{GI}_{50}$ of the latex extract for MCF-7 and T47D cell lines were $498.7 \pm 1.3 \mu \mathrm{g} / \mathrm{mL}$ and $315.7 \pm 36.6 \mu \mathrm{g} / \mathrm{mL}$, respectively (Table 1). Latex extract dose-dependently inhibited the proliferation of both triple negative cell lines, MDA-MB-231 and MDA-MB-468. At $500 \mu \mathrm{g} / \mathrm{mL}$, the proliferation of MDA-MB-231 and MDA-MB-468 were significantly reduced by $72.8 \%$ and $54.4 \%$, respectively (Figure 3c,d). Latex extract showed a significant biphasic effect in MDA-MB- 468 cells. The proliferation of MDA-MB-468 cells was significantly increased at $1.96 \mu \mathrm{g} / \mathrm{mL}-15.63 \mu \mathrm{g} / \mathrm{mL}$ of latex extract treatment, whereas the increasing 
extract concentrations $(62.5 \mu \mathrm{g} / \mathrm{mL}-500 \mu \mathrm{g} / \mathrm{mL})$ inhibited its proliferation (Figure $3 \mathrm{~d})$. The $\mathrm{GI}_{50}$ of the latex extract for MDA-MB-231 and MDA-MB-468 cell lines were $258.3 \pm 18 \mu \mathrm{g} / \mathrm{mL}$ and $499 \pm 0.8 \mu \mathrm{g} / \mathrm{mL}$, respectively (Table 1). E. bicolor latex extract at concentrations up to $62.5 \mu \mathrm{g} / \mathrm{mL}$ did not inhibit the growth of human normal primary dermal fibroblast. A decrease of up to $83 \%$ in cell viability was observed with higher concentrations of latex extract treatment (Figure 3e).

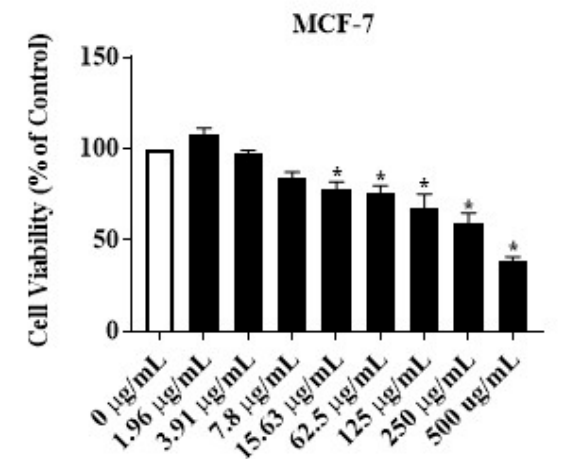

(a)

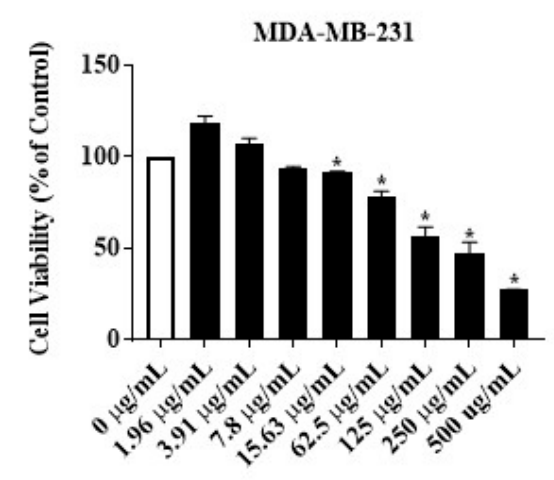

(c)

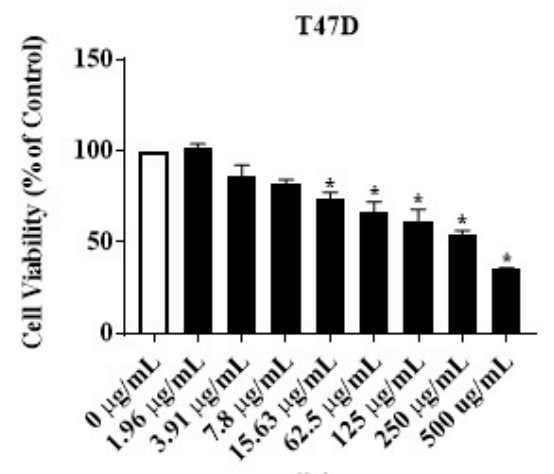

(b)

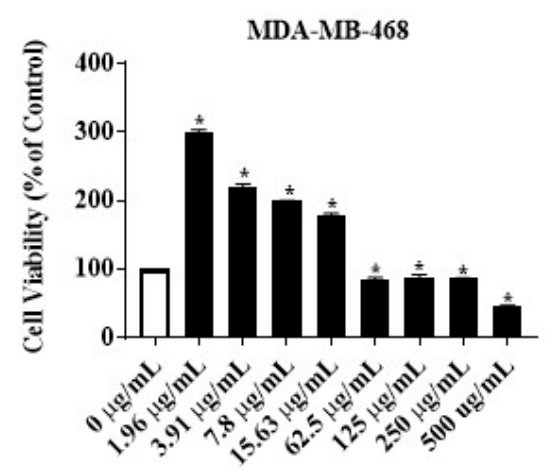

(d)

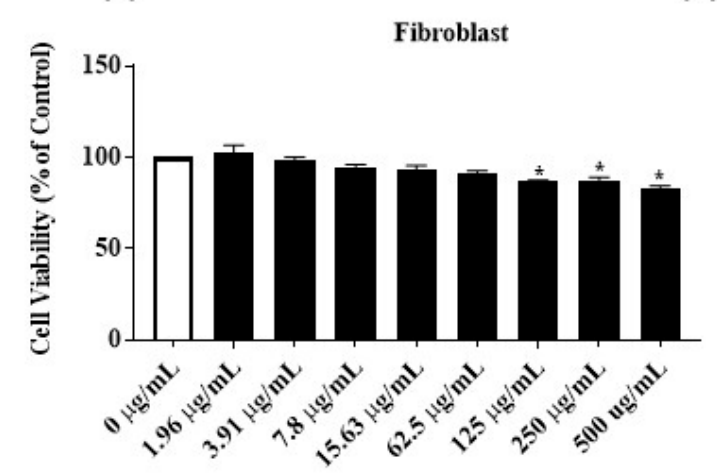

(e)

Figure 3. Antiproliferative activities of E. bicolor latex extract on ER-positive and triple negative breast cancer cell lines: (a) MCF-7 (ER+); (b) T47-D (ER+); (c) MDA-MB-231 (triple negative); (d) MDA-MB-468 (triple negative) breast cancer cell lines; and (e) effects of E. bicolor latex on the growth of human normal primary dermal fibroblast. One-way ANOVA followed by Tukey's posthoc test was performed. Bars with asterisks are significantly different from untreated control at $p \leq 0.05$. 
Table 1. The growth inhibition $50\left(\mathrm{GI}_{50}\right)$ of E. bicolor latex extract and its phytochemicals RTX and rutin in MCF-7 and T47D (ER+) and MDA-MB-231 and MDA-MB-468 (triple negative) breast carcinomas.

\begin{tabular}{cc}
\hline \multicolumn{2}{c}{ E. bicolor Latex Extract } \\
\hline Breast Carcinoma & GI $_{\mathbf{5 0}}(\mu \mathrm{g} / \mathrm{mL})$ \\
\hline MCF-7 & $498.7 \pm 1.3$ \\
T47D & $315.7 \pm 36.6$ \\
MDA-MB-231 & $258.3 \pm 18$ \\
MDA-MB-468 & $499 \pm 0.8$ \\
\hline \multicolumn{2}{c}{ RTX } \\
\hline Breast Carcinoma & GI $_{\mathbf{5 0}}(\boldsymbol{\mu M})$ \\
MCF-7 & $139 \pm 7.8$ \\
T47D & $100 \pm 23.6$ \\
MDA-MB-231 & $246.7 \pm 3.4$ \\
MDA-MB-468 & $248.5 \pm 1.5$ \\
\hline \multicolumn{2}{c}{ Rutin } \\
\hline Breast Carcinoma & GI $_{\mathbf{5 0}}(\mu \mathrm{M})$ \\
MCF-7 & $77.5 \pm 18.8$ \\
T47D & $65.7 \pm 14$ \\
MDA-MB-231 & $160 \pm 8.2$ \\
MDA-MB-468 & $383.3 \pm 54.4$ \\
\hline
\end{tabular}

Phytochemicals RTX and rutin identified in the latex extract also dose-dependently inhibited the proliferation of the ER-positive cell lines. RTX significantly reduced the proliferation of MCF-7 cells by $91 \%$ both at $250 \mu \mathrm{M}$ and $500 \mu \mathrm{M}$ and reduced the proliferation of T47-D cells by $85.1 \%$ and $95.7 \%$ at $250 \mu \mathrm{M}$ and $500 \mu \mathrm{M}$, respectively (Figure $4 \mathrm{a}, \mathrm{b}$ ). At $500 \mu \mathrm{M}$, rutin significantly reduced the proliferation of MCF-7 and T47-D cells by $83.3 \%$ and $94 \%$, respectively (Figure $5 a, b$ ). The GI 50 of RTX for MCF-7 and T47D cell lines were $139 \pm 7.8 \mu \mathrm{M}$ and $100 \pm 23.6 \mu \mathrm{M}$, respectively (Table 1). The $\mathrm{GI}_{50}$ of rutin for MCF-7 and T47D cell lines were $77.5 \pm 18.8 \mu \mathrm{M}$ and $65.7 \pm 14 \mu \mathrm{M}$, respectively (Table 1). At $500 \mu \mathrm{M}$, RTX significantly reduced the proliferation of triple negative cell lines MDA-MB-231 and MDA-MB-468 cells by $97.7 \%$ and $84 \%$, respectively (Figure $4 \mathrm{c}, \mathrm{d}$ ). Rutin also dose-dependently inhibited the proliferation of triple negative cell lines. At $500 \mu \mathrm{M}$, rutin significantly reduced the proliferation of MDA-MB-231 and MDA-MB- 468 cells by $66 \%$ and $70 \%$, respectively (Figure $5 c, d$ ). The GI 50 of RTX for MDA-MB-231 and MDA-MB-468 cell lines were $246.7 \pm 3.4 \mu \mathrm{M}$ and $248.5 \pm 1.5 \mu \mathrm{M}$, respectively (Table 1). The $\mathrm{GI}_{50}$ of rutin for MDA-MB-231 and MDA-MB-468 cell lines were $160 \pm 8.2 \mu \mathrm{M}$ and $383.3 \pm 54.4 \mu \mathrm{M}$, respectively (Table 1). The same significant biphasic effect of RTX and rutin in MDA-MB-468 cells as for the latex extract treatment was observed. The proliferation of MDA-MB-468 cells was significantly increased by lower concentrations, and decreased by higher concentrations $(250 \mu \mathrm{g} / \mathrm{mL}$ and $500 \mu \mathrm{g} / \mathrm{mL})$ of RTX and rutin (Figures $4 \mathrm{~d}$ and $5 \mathrm{~d}$ ). RTX inhibited the growth of human normal primary dermal fibroblast cells up to $82 \%$ at higher concentrations (Figure 4e). Rutin did not significantly inhibit human normal primary dermal fibroblast cell viability (Figure 5e). 


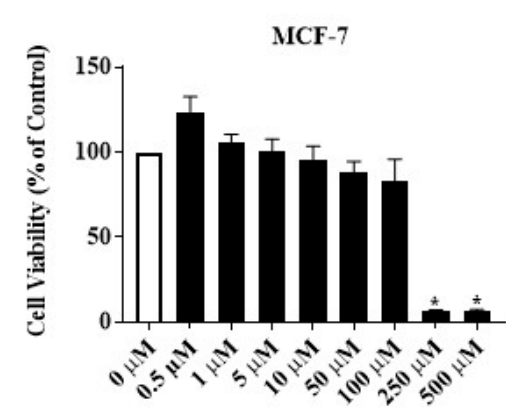

(a)

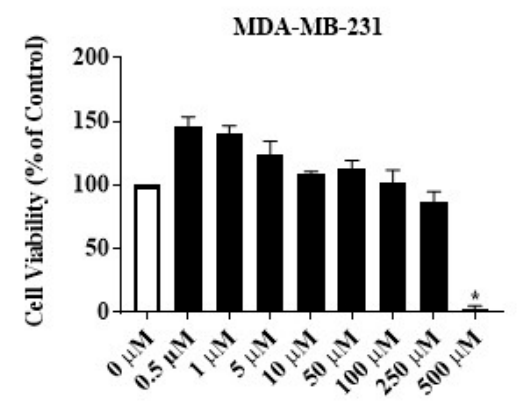

(c)

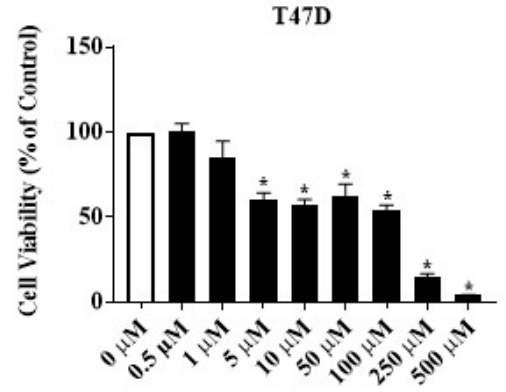

(b)

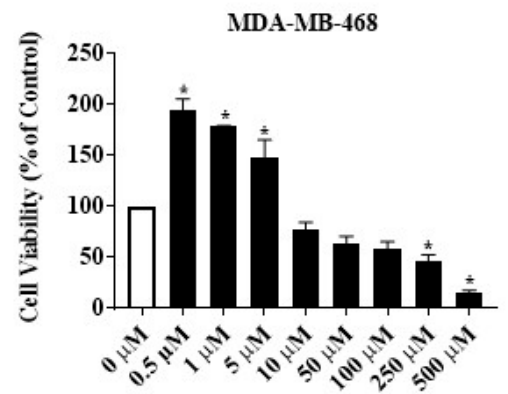

(d)

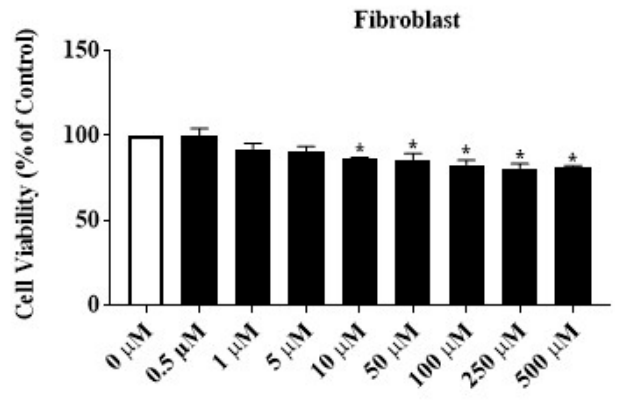

(e)

Figure 4. Antiproliferative activities of E. bicolor latex phytochemical RTX on ER-positive and triple negative breast cancer cell lines: (a) MCF-7 (ER+); (b) T47-D (ER+); (c) MDA-MB-231 (triple negative); (d) MDA-MB-468 (triple negative) breast cancer cell lines; and (e) effects of RTX on the growth of human normal primary dermal fibroblast. Bars with asterisks are significantly different from untreated control at $p \leq 0.05$ (One-way ANOVA followed by Tukey's posthoc test). 


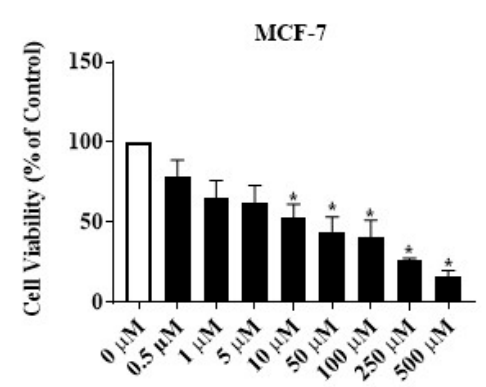

(a)

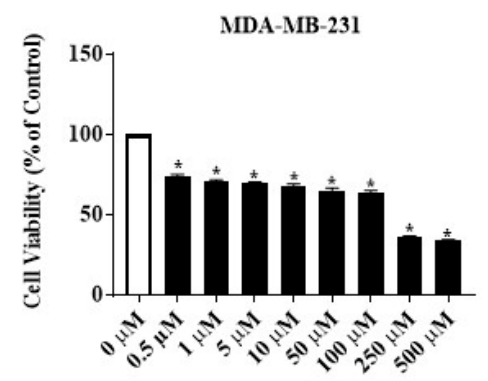

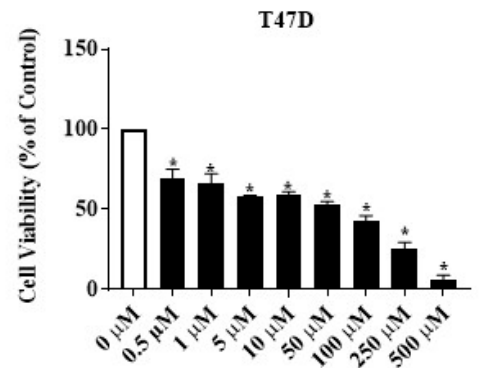

(b)

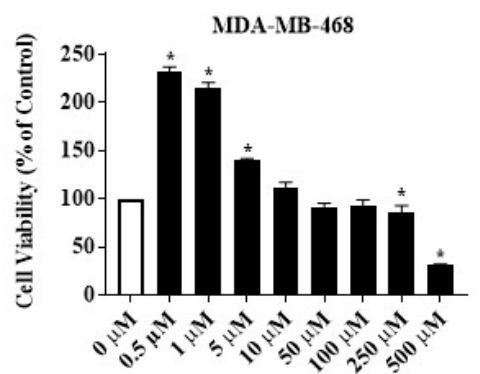

(d)

(c)

Fibroblast

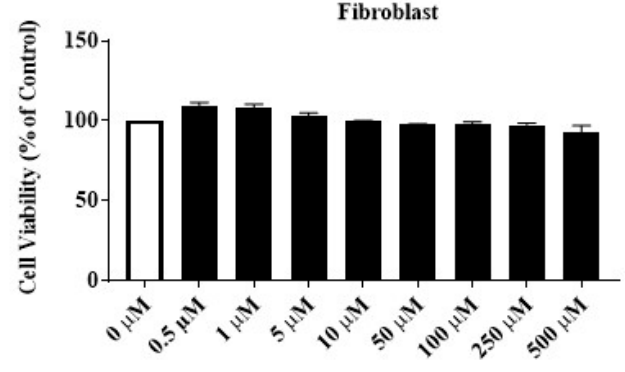

(e)

Figure 5. Antiproliferative activities of E. bicolor latex phytochemical rutin on ER-positive and triple negative breast cancer cell lines: (a) MCF-7 (ER+); (b) T47-D (ER+); (c) MDA-MB-231 (triple negative); (d) MDA-MB-468 (triple negative) breast cancer cell lines; and (e) effects of RTX on the growth of human normal primary dermal fibroblast (e). Bars with asterisks are significantly different from untreated control at $p \leq 0.05$ (One-way ANOVA followed by Tukey's posthoc test).

\subsection{Antiproliferative Activity of Latex Extract in Combination with RTX or Rutin in MCF-7 Cell Line}

To test for synergistic and additive effects, latex extract-RTX and latex extract-rutin, combination treatments of MCF-7 cells were assayed. The latex extract-RTX combination significantly reduced the proliferation of MCF-7 cells at all concentrations by $51 \%-80 \%$ (Figure $6 \mathrm{a}$ ) as compared to the individual treatment of only latex extract (Figure 6e) or RTX (Figure 6c). Similarly, the treatment of latex extract-rutin combination significantly reduced the proliferation of MCF-7 cells at all concentrations by $31.7 \%-78.2 \%$ (Figure $6 \mathrm{~b}$ ) as compared to the individual treatment of only latex extract (Figure 6e) or rutin (Figure 6d). 


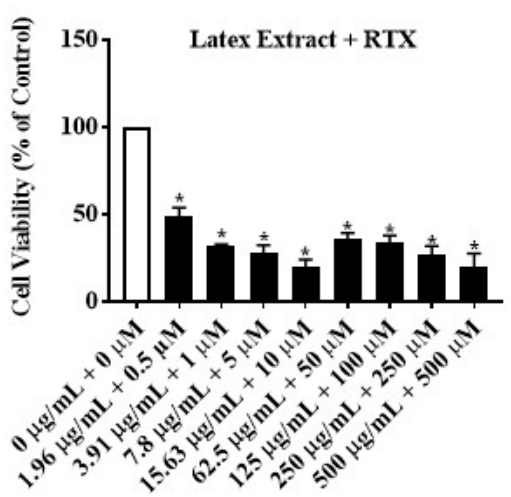

(a)

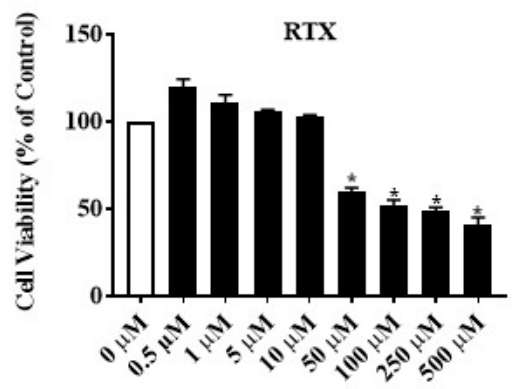

(c)

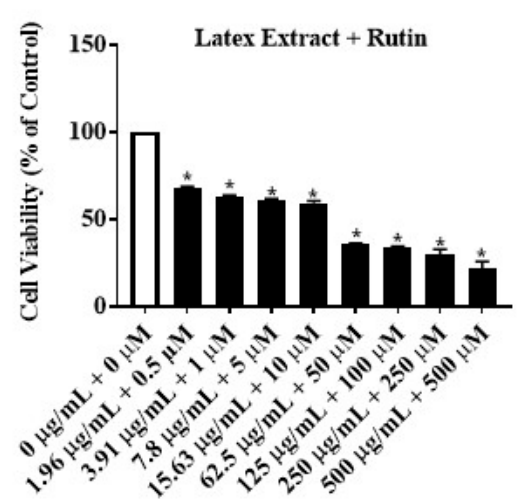

(b)

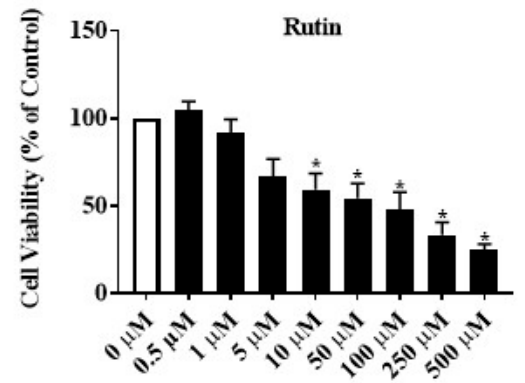

(d)

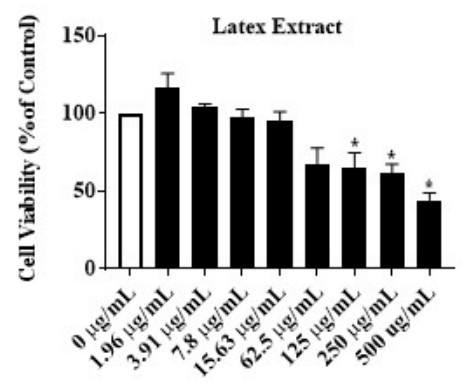

(e)

Figure 6. Antiproliferative activities of E. bicolor latex extract in combination with RTX or rutin on MCF-7 breast cancer cell line: (a) E. bicolor extract + RTX; (b) latex extract + rutin; (c) RTX; (d) rutin (e) latex extract. Cell treatment with the combination latex extract-phytochemical significantly reduced the proliferation of MCF-7 cells as compared to the corresponding individual treatments of only phytochemicals or latex extract. Bars with asterisks are significantly different from untreated control at $p \leq 0.05$ (One-way ANOVA followed by Tukey's posthoc test).

\section{Discussion}

E. bicolor latex extract and its phytochemicals showed dose-dependently antiestrogenic activities in a steroid-regulated yeast system, and induced significant antiproliferative activities in ER-positive and triple negative breast cancer cells-but not in human normal primary dermal fibroblast. In vitro yeast two hybrid system containing ER $\alpha$ or ER $\beta$ has been used previously as a potential tool for screening for estrogenic and antiestrogenic activities of several plant species [23-26]. The present study reports low estrogenic activity of the isoflavone daidzein and flavonoids chalcone, kaempferol, naringenin, quercetin, and rutin identified in E. bicolor latex extract. The low estrogenic activity of daidzein could be explained by the 1000 times lower affinity of daidzein for estrogen receptor compared to that of estradiol [27]. Resende et al.'s study showed that among a series of flavonoids tested, only kaempferol induced significant estrogenic activity in a recombinant yeast assay. Quercetin, fisetin, chrysin, luteolin, 
galangin, flavone, 3-hydroxyflavone, 5-hydroxyflavone and 7-hydroxyflavone showed no detectable estrogenic activity [28]. In our study, coumestrol $(1-5 \mu \mathrm{M})$ and genistein $(1-5 \mu \mathrm{M})$ induced high estrogenic activities. A previous study showed that coumestrol at $1 \mu \mathrm{M}$ and genistein at $10 \mu \mathrm{M}$ induced estrogenic activities comparable to the estrogenic activity of estradiol at $0.01 \mu \mathrm{M}$ in a yeast estrogen screen assay [29].

In the current study, $5 \mu \mathrm{M}$ of coumestrol, daidzein, and genistein, known phytoestrogens, induced antiestrogenic activities by inhibiting 70.7\%, 69.2\%, 90.3\% of estradiol activity, respectively. Chalcone, kaempferol, naringenin, quercetin, and, abietic acid, RTX, and rutin, identified in the E. bicolor latex extract, also induced much lower antiestrogenic activities. It has been reported that coumestrol and genistein did not exhibit antiestrogenic activities, whereas biochanin $\mathrm{A}$ and naringenin induced antiestrogenic activities at a nanomolar range in yeast estrogen screen assay [29]. The differences between the antiestrogenic activities we observed and those obtained by Collins et al. could be attributed to the employment of different yeast systems and cultural conditions [29]. The results of strong antiestrogenic activities of phytoestrogens, mainly of genistein, corroborate with their antiproliferative activity. Genistein has been reported to enhance hormonal therapy sensitivity in MDA-MB-231 [30] and induce apoptosis and autophagy in MCF-7 breast carcinomas [31].

In the present study, E. bicolor latex extract reduced the proliferation of both ER-positive (MCF-7 and T47-D) and triple negative (MDA-MB-231 and MDA-MB-468) breast cancer cell lines. The Euphorbiaceae family species are well-known for their antiproliferative properties. It was previously reported that E. hirta methanolic extract significantly inhibited the proliferation of MCF-7 cells at $24 \mathrm{~h}$ at the $\mathrm{GI}_{50}$ value of $25.26 \mu \mathrm{g} / \mathrm{mL}$ [32], much lower than that of E. bicolor latex extract in our study. Acetone extracts of E. macroclada leaves and flowers induced significant cytotoxicity in MCF-7 breast carcinoma [33]. Butanol, hexane or methanol extracts of E. tirucalli stem inhibited the proliferation of MCF-7 and MDA-MB-231 in a concentration dependent manner [19]. In another study, dichloromethane and ethyl acetate extracts of E. macroclada exhibited cytotoxic effects on MDA-MB-468 cancer cell line, while the methanol extract and latex extract in DMSO were not cytotoxic at the tested concentrations [34]. Sadeghi-Aliabadi et al. reported that the nonpolar extracts of E. macroclada possess higher cytotoxic activity than the polar extracts [34]. In our study, the polar methanolic extract of E. bicolor latex possessed antiproliferative activities on both ER-positive and triple negative breast carcinomas. Other species of Euphorbia were reported to possess antiproliferative activities against different breast carcinomas, such as E. szovitsii in MDA-MB-231 [18], E. humifusa in MCF-7, T47-D, and MDA-MB-231 [35], and E. fischeriana in MCF-7 [36]. The results of above-mentioned studies show that different solvent extracts of Euphorbia species and different plant tissues possess antiproliferative activities against different breast cancer cell lines. Various solvents extract different classes of Euphorbia phytochemicals and that explains differences in the antiproliferative activities induced in breast cancer cell lines. Thus, differences in the degree of antiproliferative activity results between our and other studies could be attributed to the presence of different groups of phytochemicals in extracts and solvent extraction procedures of different plant tissues. Among the above cited studies, only few report identified chemicals in the Euphorbia species and most of those chemicals are flavonoids and terpenoids $[17,19,36]$, as we identified in E. bicolor latex extract. Obtusifoliol-related steroids also were identified in E. sogdiana [17].

The present study showed that RTX significantly inhibited the proliferation of all breast carcinomas employed in the study. RTX is a potent agonist of the transient receptor potential vanilloid 1 (TRPV1) [37], a non-selective cation channel with high calcium permeability, that is mostly studied in pain research involving the central and peripheral terminals of small diameter sensory neurons [38]. The presence of TRPV1 in MCF-7 breast carcinoma also has been reported [39]. The growth inhibitory activity of RTX in MCF-7 cell cultures was reported previously but no mechanism of action was described [39,40]. RTX also induced apoptosis in the human bladder cancer cell lines T24 and 5637, being associated with mitochondrial dysfunction [41]. As reported by another study [42], in our study we also observed that low micromolar concentrations of RTX treatment showed a trend in increasing the proliferation of all cell lines, including the human normal primary dermal fibroblast cell line, but the increase was 
significant only for MDA-MB-468. However, at high concentrations, RTX decreased proliferation of all cancer cell lines under study. Pecze et al. reported that at low micromolar concentrations RTX was unable to reduce the cell viability of MCF-7 MDA-MB-231 and BT-474 cells, which was decreased at high RTX doses. The cytotoxic mechanisms of RTX in the above cancer cell lines are based on strong sodium and calcium influx via TRPV1 channels, which lead to mitochondrial calcium accumulation and necrotic cell swelling [42]. The results of RTX treatment of T47-D and MDA-MB-468 breast carcinomas in our study are novel, since no other studies have reported the antiproliferative activity of RTX in these cell lines.

Rutin, a flavonoid glycoside ( $\alpha$-L-rhamnopyranosyl- $(1 \rightarrow 6)-\beta$-D-glucopyranose), identified in the E. bicolor latex extract, also showed antiproliferative activities on all four breast cancer cell lines in the present study. Another study has shown that grape stem extract rich in flavonols, particularly rutin, inhibited the growth of MCF-7 cancer cell line [43]. Elsayed et al. reported that rutin inhibited c-Met kinase activity in the triple negative breast cancer cell line, significantly reducing the growth of MDA-MB-231/GFP orthotopic xenograft in nude mouse model [44]. Rutin is a common dietary flavonoid found in fruits, vegetables, and plant-derived beverages [45]. In vivo, gut microflora metabolizes rutin to a variety of compounds, such as quercetin and phenol derivatives [46]. It has been shown that flavonoid metabolites of parent compounds are responsible for antiproliferative activity in colorectal cancer [47]. Moreover, extraction procedures can contribute to rutin transformation. Dawidowicz et al. obtained at least 23 compounds formed from rutin during simulated and real extraction of elderberry flowers with methanol and methanol-water solvents [48]. It is possible that the antiproliferative activities observed in our study are due to such rutin derivatives obtained during E. bicolor latex extraction. Since rutin demonstrates beneficial pharmacological activities, such as antioxidant, vasoprotective, anticarcinogen, and neuroprotective properties to mention just a few [45]-more stable, and more absorbent non-toxic analogs and derivatives have been synthesized [49], making them promising potential nutraceuticals.

Many phytoestrogens (flavonoids, stilbenes and cumestans) appear to have a biphasic effect on cell proliferation, stimulating growth at low concentrations and suppressing growth at high concentrations. Genistein was shown to increase growth in estrogen-sensitive cells at low concentrations, but decreased cell growth, suppressed DNA synthesis, and induced cell death at high concentrations [50,51]. A study revealed that the proliferation observed in daidzein-treated MCF7 cells was blocked by the antiestrogen ICI 182,780, indicating that the stimulatory effect exerted by daidzein was ER-mediated [52]. Some of these effects are explained by the interactions of phytoestrogens with ER subtypes, which recruit cofactors, regulate gene expression and stimulate or inhibit the growth of breast carcinomas in different ways [53]. Therefore, in the present study, the biphasic effects of E. bicolor latex extract or its phytochemicals RTX or rutin towards different breast carcinomas under study could be explained by the agonistic/antagonistic effects of low vs. high concentrations of the latex extract or its phytochemicals for different ER subtypes. It is also of interest to note the possible role of G protein-coupled estrogen receptors (GPERs) in proliferation, since many phytoestrogens activate GPERs. In particular, genistein has been reported to stimulate growth of MCF-7 cells through a GPER-dependent mechanism [54]. The intake of soy products, rich in genistein, has been attributed to lower incidence of breast cancer in Asian vs. Western populations and epidemiologic studies showed an inverse relation between soy-rich diet and cancer risk [55,56]. Low dose $(<10 \mu \mathrm{mol} / \mathrm{L})$ of genistein has agonistic effects as estrogen activator raising breast cancer risk and high dose $(>10 \mu \mathrm{mol} / \mathrm{L})$ possesses antiproliferative effects ([56] and references within). A clinical study showed that a daily dose of $54 \mathrm{mg}$ of purified genistein did not induce breast or uterine carcinogenicity [57]. However, most clinical studies failed to report a protective effect of high genistein intake against breast cancer risk (reviewed in 56). Therefore, genistein bioactivity is not solely dependent on dose, other factors being involved.

The latex extract and phytochemicals RTX or rutin used in our study did not practically reduce the proliferation of human normal primary dermal fibroblast. Farfariello et al. showed that RTX did not induce cell death in normal human urothelial cells, which supports the findings of the 
present study [41]. A previous study assessing the effects of rutin on human normal primary dermal fibroblast [58], also supports the findings of our study, thus suggesting that the latex phytochemical rutin targets cancer cells and spares normal cells.

Results from the combination treatments of latex extract with RTX or rutin showed synergistic antiproliferative effect at lower concentrations and additive effects at higher concentrations in MCF-7 cells as compared to individual latex extract or phytochemical treatments. It seems that the latex extract-RTX and latex extract-rutin combinations worked via different pathways to inhibit cell proliferation. Deveci et al. reported that TRPV1-mediated $\mathrm{Ca}^{2+}$ entry stimulated chemotherapeutic agent 5-flurouracil induced apoptotic cell death in MCF-7 cells via up-regulation of mitochondrial oxidative stress, caspase, and PARP by a $\mathrm{Ca}^{2+}$ signaling molecular pathway [59]. Another study showed that TRPV1 agonist capsaicin enhanced intracellular calcium concentration and thus increased intracellular reactive oxygen species, mitochondrial membrane depolarization, apoptosis, PARP, and caspase activities in MCF-7 carcinomas in response to chemotherapeutic agent doxorubicin and melatonin [60]. Thus, it can be speculated that, in the present study, latex extract-RTX treatment enhanced the antiproliferative activity in MCF-7 cells through the TRPV1-induced $\mathrm{Ca}^{2+}$ signaling pathway. Another study showed that rutin acted as a chemosensitizer by increasing the cytotoxicity of two chemotherapeutic drugs, cyclophosphamide and methotrexate, in MDA-MB-231 cancer cells [58]. The role of calcium in the proliferation and invasion of cancer cells, as well as the increased expression of calcium channels in some cancers, led to the assessment of calcium channel inhibitors as potential therapy for cancer [61,62]. It is important to find new chemotherapeutics with unique effective mechanisms of action for treating cancers. Thus, transient receptor potential cation channels (TRP) become cancer-relevant targets for cancer therapies, modulated by natural products as potential anti-cancer agents.

\section{Conclusions}

To the best of our knowledge, this is the first study reporting the estrogenic and antiestrogenic activities of E. bicolor latex extract and its identified phytochemicals in a steroid-regulated yeast system, and the antiproliferative activities of the latex extract and two of its phytochemicals, RTX and rutin in both ER-positive and triple negative breast carcinomas. The latex extract and its phytochemicals are effective in inhibiting both ER-positive MCF-7 and T47-D and triple negative MDA-MB-231 and MDA-MB-468 human breast cancer cell lines, but not the human normal primary dermal fibroblast cells. Latex extract-RTX and latex-rutin combination treatments showed synergistic effects at low concentrations and additive effects at high concentrations in reducing MCF-7 cell proliferation, indicative of more than one potent phytochemical in the latex and mechanistic pathway. With future studies elucidating the molecular mechanisms of action of the latex phytochemicals in both ER-positive and triple negative breast cancer cell lines, new potential breast cancer therapeutics could be developed. A deeper understanding of TRPV1 channel biology in cancer cell-lines will open opportunities for finding natural products and developing new anti-cancer agents.

Author Contributions: Conceptualization, and study design, P.B., E.M. and C.M.; Investigation, P.B. and E.M.; Resources, M.B. and C.M.; Formal analysis, P.B., E.M., M.B. and C.M.; Manuscript Writing and Preparation, P.B., E.M., M.B. and C.M. All authors have read and agreed to the published version of the manuscript.

Funding: This research was supported by a TWU Research Enhancement Grant to CM and a TWU Quality Enhancement Program 'Learn by Doing' grant to PB.

Acknowledgments: The authors thank Amon Gekombe, Carrie Wilks, and Rituparna Sinha Roy for technical assistance.

Conflicts of Interest: The authors declare no conflict of interest. The funders had no role in the design of the study; in the collection, analyses, or interpretation of data; in the writing of the manuscript, or in the decision to publish the results. 


\section{References}

1. American Institute for Cancer Research. Worldwide Cancer Data-Global Cancer Statistics for the Most Common Cancers. Available online: https://www.wcrf.org/dietandcancer/cancer-trends/worldwide-cancerdata (accessed on 10 October 2019).

2. National Cancer Institute. Cancer Stat Facts: Female Breast Cancer. Available online: https://seer.cancer.gov/ statfacts/html/breast.html (accessed on 10 October 2019).

3. Hua, H.; Zhang, H.; Kong, Q.; Jiang, Y. Mechanisms for estrogen receptor expression in human cancer. Exp. Hematol. Oncol. 2018, 7,1-11. [CrossRef] [PubMed]

4. Huang, W.; Peng, Y.; Kiselar, J.; Zhao, X.; Albaqami, A.; Mendez, D.; Chen, Y.; Chakravarthy, S.; Gupta, S.; Ralston, C.; et al. Multidomain architecture of estrogen receptor reveals interfacial cross-talk between its DNA-binding and ligand-binding domains. Nat. Commun. 2018, 9, 3520. [CrossRef] [PubMed]

5. Carey, L.; Winer, E.; Viale, G.; Cameron, D.; Gianni, L. Triple-negative breast cancer: Disease entity or title of convenience? Nat. Rev. Clin. Oncol. 2010, 7, 683. [CrossRef] [PubMed]

6. Marino, M.; Galluzzo, P.; Ascenzi, P. Estrogen signaling multiple pathways to impact gene transcription. Curr. Genom. 2006, 7, 497-508. [CrossRef]

7. McDonnell, D.P.; Norris, J.D. Connections and regulation of the human estrogen receptor. Science 2002, 296, 1642-1644. [CrossRef]

8. Siersbæk, R.; Kumar, S.; Carroll, J.S. Signaling pathways and steroid receptors modulating estrogen receptor $\alpha$ function in breast cancer. Genes Dev. 2018, 32, 1141-1154. [CrossRef]

9. Ali, S.; Coombes, R.C. Estrogen receptor alpha in human breast cancer: Occurrence and significance. J. Mammary Gland Biol. Neoplasia 2000, 5, 271-281. [CrossRef]

10. Jensen, E.V.; Jordan, V.C. The estrogen receptor: A model for molecular medicine. Clin. Cancer Res. 2003, 9 , 1980-1989.

11. Nussbaumer, S.; Bonnabry, P.; Veuthey, J.-L.; Fleury-Souverain, S. Analysis of anticancer drugs: A review. Talanta 2011, 85, 2265-2289. [CrossRef]

12. Lumachi, F.; Brunello, A.; Maruzzo, M.; Basso, U.; Basso, S.M. Treatment of estrogen receptor-positive breast cancer. Curr. Med. Chem. 2013, 20, 596-604. [CrossRef]

13. Monsuez, J.-J.; Charniot, J.-C.; Vignat, N.; Artigou, J.-Y. Cardiac side-effects of cancer chemotherapy. Int. J. Cardiol. 2010, 144, 3-15. [CrossRef] [PubMed]

14. Dropcho, E.J. The neurologic side effects of chemotherapeutic agents. CONTINUUM Lifelong Learn. Neurol. 2011, 17, 95-112. [CrossRef] [PubMed]

15. Basu, P.; Maier, C. Phytoestrogens and breast cancer: In vitro anticancer activities of isoflavones, lignans, coumestans, stilbenes and their analogs and derivatives. Biomed. Pharmacother. 2018, 107, 1648-1666. [CrossRef] [PubMed]

16. Newman, D.J.; Cragg, G.M. Natural products as sources of new drugs over the 30 years from 1981 to 2010. J. Nat. Prod. 2012, 75, 311-335. [CrossRef] [PubMed]

17. Aghaei, M.; Yazdiniapour, Z.; Ghanadian, M.; Zolfaghari, B.; Lanzotti, V.; Mirsafaee, V. Obtusifoliol related steroids from Euphorbia sogdiana with cell growth inhibitory activity and apoptotic effects on breast cancer cells (MCF-7 and MDA-MB231). Steroids 2016, 115, 90-97. [CrossRef]

18. Asadi-Samani, M.; Rafieian-Kopaei, M.; Lorigooini, Z.; Shirzad, H. The effect of Euphorbia szovitsii Fisch. \& C.A. Mey extract on the viability and the proliferation of MDA-MB-231 cell line. Biosci. Rep. $2019,39$. [CrossRef]

19. Choene, M.; Motadi, L. Validation of the antiproliferative effects of Euphorbia tirucalli extracts in breast cancer cell lines. Mol. Biol. 2016, 50, 98-110. [CrossRef]

20. Chen, X.; Chen, X.; Liu, X.; Wink, M.; Ma, Y.; Guo, Y. A myrsinol diterpene isolated from Euphorbia prolifera reverses multidrug resistance in breast cancer cells. Pharmazie 2016, 71, 537-539.

21. Basu, P.; Tongkhuya, S.; Harris, T.L.; Riley, A.R.; Maier, C.; Granger, J.; Wojtaszek, J.; Averitt, D. Euphorbia bicolor (Euphorbiaceae) latex phytochemicals induce long-lasting non-opioid peripheral analgesia in a rat model of inflammatory pain. Front. Pharmacol. 2019, 10. [CrossRef] 
22. Santiso-Mere, D.N.; Nawaz, Z.; McDonnell, D.P.; O'Malley, B.W. The development of S. cerevisiae as a host system for steroid hormone action studies. In Hormone Action and Molecular Endocrinology; Huges, M.R., Schrader, W.T., O’Malley, B.W., Eds.; Houston Biological Associates Inc.: Houston, TX, USA, 1991; pp. 23-1-23-24.

23. Maier, C.; Chapman, K.; Smith, D.W. Differential estrogenic activities of male and female plant extracts from two dioecious species. Plant Sci. 1995, 109, 31-43. [CrossRef]

24. Basu, P.; Dixon, D.; Varghese, S.; Maier, C. Detection of estrogenic, antiestrogenic, and drug synergistic activities of seven commercially available fruits by in vitro reporter assays. Pharmacogn. Res. 2018, 10, 137-142.

25. Boonchird, C.; Mahapanichkul, T.; Cherdshewasart, W. Differential binding with ER $\alpha$ and ER $\beta$ of the phytoestrogen-rich plant Pueraria mirifica. Braz. J. Med. Biol. Res. 2010, 43, 195-200. [CrossRef] [PubMed]

26. El-Halawany, A.M.; El Dine, R.S.; Chung, M.H.; Nishihara, T.; Hattori, M. Screening for estrogenic and antiestrogenic activities of plants growing in Egypt and Thailand. Pharmacogn. Res. 2011, 3, 107-113.

27. Shutt, D.A.; Cox, R.I. Steroid and phyto-oestrogen binding to sheep uterine receptors in vitro. J. Endocrinol. 1972, 52, 299-310. [CrossRef] [PubMed]

28. Resende, F.A.; de Oliveira, A.P.S.; de Camargo, M.S.; Vilegas, W.; Varanda, E.A. Evaluation of estrogenic potential of flavonoids using a recombinant yeast strain and MCF7/BUS cell proliferation assay. PLoS ONE 2013, 8, e74881. [CrossRef] [PubMed]

29. Collins, B.M.; McLachlan, J.A.; Arnold, S.F. The estrogenic and antiestrogenic activities of phytochemicals with the human estrogen receptor expressed in yeast. Steroids 1997, 62, 365-372. [CrossRef]

30. Li, Y.; Meeran, S.M.; Patel, S.N.; Chen, H.; Hardy, T.M.; Tollefsbol, T.O. Epigenetic reactivation of estrogen receptor- $\alpha(\mathrm{ER} \alpha)$ by genistein enhances hormonal therapy sensitivity in ER $\alpha$-negative breast cancer. Mol. Cancer 2013, 12, 9. [CrossRef]

31. Prietsch, R.F.; Monte, L.G.; da Silva, F.A.; Beira, F.T.; Del Pino, F.A.B.; Campos, V.F.; Collares, T.; Pinto, L.S.; Spanevello, R.M.; Gamaro, G.D.; et al. Genistein induces apoptosis and autophagy in human breast MCF-7 cells by modulating the expression of proapoptotic factors and oxidative stress enzymes. Mol. Cell. Biochem. 2014, 390, 235-242. [CrossRef]

32. Kwan, Y.P.; Saito, T.; Ibrahim, D.; Al-Hassan, F.M.; Ein Oon, C.; Chen, Y.; Jothy, S.L.; Kanwar, J.R.; Sasidharan, S. Evaluation of the cytotoxicity, cell-cycle arrest, and apoptotic induction by Euphorbia hirta in MCF-7 breast cancer cells. Pharm. Biol. 2016, 54, 1223-1236.

33. Taş, A.; Şahin-Bölükbaşı, S.; Çevik, E.; Özmen, E.; Gümüş, E.; Siliğ, Y. An in vitro study of cytotoxic activity of Euphorbia macroclada boiss on MCF-7 cells. Indian J. Pharm. Educ. Res. 2018, 52, S119-S123. [CrossRef]

34. Sadeghi-Aliabadi, H.; Sajjadi, S.E.; Khodamoradi, M. Cytotoxicity of Euphorbia macroclada on MDA-MB-468 breast cancer cell line. Iran. J. Pharm. Sci. 2009, 5, 103-108.

35. Shin, S.Y.; Kim, C.G.; Jung, Y.J.; Jung, Y.; Jung, H.; Im, J.; Lim, Y.; Lee, Y.H. Euphorbia humifusa Willd exerts inhibition of breast cancer cell invasion and metastasis through inhibition of TNF $\alpha$-induced MMP-9 expression. BMC Complement. Altern. Med. 2016, 16, 413. [CrossRef] [PubMed]

36. Kuang, X.; Li, W.; Kanno, Y.; Yamashita, N.; Kikkawa, S.; Azumaya, I.; Nemoto, K.; Asada, Y.; Koike, K. Euphorins A-H: Bioactive diterpenoids from Euphorbia fischeriana. J. Nat. Med. 2016, 70, 412-422. [CrossRef] [PubMed]

37. Raisinghani, M.; Pabbidi, R.M.; Premkumar, L.S. Activation of transient receptor potential vanilloid 1 (TRPV1) by resiniferatoxin. J. Physiol. 2005, 567, 771-786. [CrossRef]

38. Caterina, M.J.; Schumacher, M.A.; Tominaga, M.; Rosen, T.A.; Levine, J.D.; Julius, D. The capsaicin receptor: A heat-activated ion channel in the pain pathway. Nature 1997, 389, 816-824. [CrossRef]

39. Vercelli, C.; Barbero, R.; Cuniberti, B.; Racca, S.; Abbadessa, G.; Piccione, F.; Re, G. Transient receptor potential vanilloid 1 expression and functionality in MCF-7 cells: A preliminary investigation. J. Breast Cancer 2014, 17, 332-338. [CrossRef]

40. Vercelli, C.; Barbero, R.; Cuniberti, B.; Odore, R.; Re, G. Expression and functionality of TRPV1 receptor in human MCF-7 and canine CF.41 cells. Vet. Comp. Oncol. 2015, 13, 133-142. [CrossRef]

41. Farfariello, V.; Liberati, S.; Morelli, M.B.; Tomassoni, D.; Santoni, M.; Nabissi, M.; Giannantoni, A.; Santoni, G.; Amantini, C. Resiniferatoxin induces death of bladder cancer cells associated with mitochondrial dysfunction and reduces tumor growth in a xenograft mouse model. Chem. Biol. Interact. 2014, 224, 128-135. [CrossRef] 
42. Pecze, L.; Jósvay, K.; Blum, W.; Petrovics, G.; Vizler, C.; Oláh, Z.; Schwaller, B. Activation of endogenous TRPV1 fails to induce overstimulation-based cytotoxicity in breast and prostate cancer cells but not in pain-sensing neurons. Biochim. Biophys. Acta 2016, 1863, 2054-2064. [CrossRef]

43. Sahpazidou, D.; Geromichalos, G.D.; Stagos, D.; Apostolou, A.; Haroutounian, S.A.; Tsatsakis, A.M.; Tzanakakis, G.N.; Hayes, A.W.; Kouretas, D. Anticarcinogenic activity of polyphenolic extracts from grape stems against breast, colon, renal and thyroid cancer cells. Toxicol. Lett. 2014, 230, 218-224. [CrossRef]

44. Elsayed, H.E.; Ebrahim, H.Y.; Mohyeldin, M.M.; Siddique, A.B.; Kamal, A.M.; Haggag, E.G.; El Sayed, K.A. Rutin as a novel c-Met inhibitory lead for the control of triple negative breast malignancies. Nutr. Cancer 2017, 69, 1256-1271. [CrossRef] [PubMed]

45. Ganeshpurkar, A.; Saluja, A.K. The pharmacological potential of rutin. Saudi Pharm. J. 2017, 25, $149-164$. [CrossRef] [PubMed]

46. Pashikanti, S.; de Alba, D.R.; Boissonneault, G.A.; Cervantes-Laurean, D. Rutin metabolites: Novel inhibitors of nonoxidative advanced glycation end products. Free Radic. Biol. Med. 2010, 48, 656-663. [CrossRef] [PubMed]

47. Sankaranarayanan, R.; Valiveti, C.K.; Kumar, D.R.; Kesharwani, S.S.; Seefeldt, T.; Scaria, J.; Tumala, H.; Bhat, G.J. The flavonoid metabolite 2, 4, 6-trihydroxybenzoic acid is a CDK inhibitor and an anti-proliferative agent: A potential role in cancer prevention. Cancers 2019, 11, 427. [CrossRef] [PubMed]

48. Dawidowicz, A.L.; Bernacik, K.; Typek, R. Rutin transformation during its analysis involving extraction process for sample preparation. Food Anal. Methods 2016, 9, 213-224. [CrossRef]

49. Mecenas, A.S.; Malafaia, C.R.A.; Sangenito, L.S.; Simas, D.L.R.; de Barros Machado, T.; Amaral, A.C.F.; dos Santos, A.J.S.; Freire, D.M.G.; Leal, I.C.R. Rutin derivatives obtained by transesterification reactions catalyzed by Novozym 435: Antioxidant properties and absence of toxicity in mammalian cells. PLoS ONE 2018, 13, e0203159. [CrossRef]

50. Maggiolini, M.; Bonofiglio, D.; Marsico, S.; Panno, M.L.; Cenni, B.; Picard, D.; Andò, S. Estrogen receptor $\alpha$ mediates the proliferative but not the cytotoxic dose-dependent effects of two major phytoestrogens on human breast cancer cells. Mol. Pharm. 2001, 60, 595-602.

51. Seo, H.S.; DeNardo, D.G.; Jacquot, Y.; Laïos, I.; Vidal, D.S.; Zambrana, C.R.; Leclercq, G.; Brown, P.H. Stimulatory effect of genistein and apigenin on the growth of breast cancer cells correlates with their ability to activate ER alpha. Breast Cancer Res. Treat. 2006, 99, 121-134. [CrossRef]

52. Ju, Y.H.; Fultz, J.; Allred, K.F.; Doerge, D.R.; Helferich, W.G. Effects of dietary daidzein and its metabolite, equol, at physiological concentrations on the growth of estrogen-dependent human breast cancer (MCF-7) tumors implanted in ovariectomized athymic mice. Carcinogenesis 2006, 27, 856-863. [CrossRef]

53. Lecomte, S.; Demay, F.; Ferrière, F.; Pakdel, F. Phytochemicals Targeting Estrogen Receptors: Beneficial Rather Than Adverse Effects? Int. J. Mol. Sci. 2017, 18, 1381. [CrossRef]

54. Prossnitz, E.R.; Barton, M. The G-protein-coupled estrogen receptor GPER in health and disease. Nat. Rev. Endocrinol. 2011, 7, 715-726. [CrossRef] [PubMed]

55. Spagnuolo, C.; Russo, G.L.; Orhan, I.E.; Habtemariam, S.; Daglia, M.; Sureda, A.; Nabavi, S.F.; Devi, K.P.; Loizzo, M.R.; Tundis, R.; et al. Genistein and cancer: Current status, challenges, and future directions. Adv. Nutr. 2015, 6, 408-419. [CrossRef] [PubMed]

56. Liu, R.; Yu, X.; Chen, X.; Zhong, H.; Liang, C.; Xu, X.; Xu, W.; Cheng, W.; Wang, W.; Yu, L.; et al. Individual factors define the overall effects of dietary genistein exposure on breast cancer patients. Nutr. Res. 2019. [CrossRef] [PubMed]

57. Marini, H.; Bitto, A.; Altavilla, D.; Burnett, B.P.; Polito, F.; Di Stefano, V.; Minutoli, L.; Atteritano, M.; Levy, R.M.; D'Anna, R.; et al. Breast safety and efficacy of genistein aglycone for postmenopausal bone loss: A follow-up study. J. Clin. Endocrinol. Metab. 2008, 93, 4787-4796. [CrossRef] [PubMed]

58. Iriti, M.; Kubina, R.; Cochis, A.; Sorrentino, R.; Varoni, E.M.; Kabała-Dzik, A.; Azzimonti, B.; Dziedzic, A.; Rimondini, L.; Wojtyczka, R.D. Rutin, a quercetin glycoside, restores chemosensitivity in human breast cancer cells. Phytother. Res. 2017, 31, 1529-1538. [CrossRef]

59. Deveci, H.A.; Nazıroğlu, M.; Nur, G. 5-Fluorouracil-induced mitochondrial oxidative cytotoxicity and apoptosis are increased in MCF-7 human breast cancer cells by TRPV1 channel activation but not Hypericum perforatum treatment. Mol. Cell. Biochem. 2018, 439, 189-198. [CrossRef] 
60. Koşar, P.A.; Nazıroğlu, M.; Övey, İ.S.; Çiğ, B. Synergic effects of doxorubicin and melatonin on apoptosis and mitochondrial oxidative stress in MCF-7 breast cancer cells: Involvement of TRPV1 channels. J. Membr. Biol. 2016, 249, 129-140. [CrossRef]

61. Rodrigues, T.; Sieglitz, F.; Bernardes, G.J. Natural product modulators of transient receptor potential (TRP) channels as potential anti-cancer agents. Chem. Soc. Rev. 2016, 45, 6130-6137. [CrossRef]

62. Peterson, J.; Doughty, H.; Eells, A.; Johnson, T.; Hastings, J.P.; Crowther, C.M.; Andrus, M.B.; Kenealey, J.D. The effects of $4^{\prime}$-esterified resveratrol derivatives on calcium dynamics in breast cancer cells. Molecules 2017, 22, 1968. [CrossRef]

(C) 2019 by the authors. Licensee MDPI, Basel, Switzerland. This article is an open access article distributed under the terms and conditions of the Creative Commons Attribution (CC BY) license (http://creativecommons.org/licenses/by/4.0/). 